\title{
Issue Competition without Electoral Incentives? A Study of Issue Emphasis in the European Parliament
}

\author{
Maurits J. Meijers, Radboud University \\ Harmen van der Veer, Leiden University
}

\begin{abstract}
Niche party leverage over mainstream party policy agendas is a central theme in the issue competition literature. The literature has underlined that the electoral threat associated with niche party issue mobilization guides mainstream party responses to such niche parties. Yet how do political parties react to issue mobilization in an institutional setting not primarily steered by electoral considerations? We argue that the European Parliament constitutes such a case and study issue competition on the radical right's core issue: immigration. To establish the leverage of radical right members of the European Parliament (MEPs), we use an original data set of parliamentary questions and motions between 2004 and 2016. Using time-series regression analysis, we find that mainstream party groups do not increase their emphasis of immigration issues in response to radical right MEPs' issue emphasis. These findings indicate that the institutional context and the perceived electoral threat are crucial for issue competition dynamics.
\end{abstract}

$n$ recent years, evidence has mounted that mainstream political parties respond to the threat of radical right parties by increasingly emphasizing the radical right's core issue: immigration (Abou-Chadi 2016; Bale et al. 2010; Meguid 2005; van de Wardt 2015). The issue competition literature underlines that niche parties, including the radical right, have an interest in stressing issues that were previously ignored by mainstream parties and that do not match the dominant lines of political conflict (De Vries and Hobolt 2012; Meguid 2005). In turn, gauging the extent of the electoral threat of the niche party in question, mainstream parties devise a response strategy. When the niche party threat is considerable, mainstream parties tend to increasingly emphasize the issue. Yet, when the niche party threat is absent or weak, mainstream parties are usually prone to adopt a dismissive strategy to keep the issue off the agenda (Meguid 2008, 99-103). Hence, a key argument of this literature is that parties do not have a monopoly over their own agenda but are forced to be responsive to one another when devising their issue emphasis strategies. Crucially, such electoral drivers of issue competition are not limited to the electoral arena but are also found in the parliamentary arena (Green-Pedersen 2010; Otjes 2011; van de
Wardt 2015; Vliegenthart, Walgrave, and Meppelink 2011; Vliegenthart, Walgrave, and Zicha 2013).

Yet, how do political parties react to niche party issue mobilization in a parliamentary setting in which institutional factors constrain niche party leverage? The European Parliament (EP) is such a parliament. In contrast to domestic parliaments, the EP's parliamentary arena is disconnected from its electoral arena(s) (Hix and Høyland 2013). In the electoral arena, national parties compete with domestic competitors over seats in the EP. In the parliamentary arena, however, European party groups compete with each other in the EP over policy (Hix 2002b). Furthermore, the extreme dominance of mainstream party groups within the EP is likely to affect issue competition dynamics (Kreppel and Tsebelis 1999). Unlike in the domestic context, niche party behavior in the EP is therefore less likely to have electoral consequences for the mainstream party groups.

In line with issue competition theory, we argue that the absence of a veritable electoral threat of radical right parties in the EP motivates mainstream party groups to adopt a dismissive strategy by decreasing their emphasis of the immigration issue. Given the growing presence of radical right

Maurits J. Meijers (m.meijers@fm.ru.nl) is an assistant professor of comparative politics at the Department of Political Science, Radboud University, Nijmegen, the Netherlands. Harmen van der Veer (h.a.a.vanderveer@uva.nl) is a lecturer at Leiden University, the Netherlands.

Support for this research was provided by the Netherlands Organisation for Scientific Research grant 406-14-118. Data and supporting materials necessary to reproduce the numerical results in the article are available in the JOP Dataverse (https://dataverse.harvard.edu/dataverse/jop). An online appendix with supplementary material is available at https://dx.doi.org/10.1086/704224.

The Journal of Politics, volume 81, number 4. Published online June 12, 2019. http://dx.doi.org/10.1086/704224

(C) 2019 by the Southern Political Science Association. All rights reserved. 0022-3816/2019/8104-00XX\$10.00 
parties in the EP (Treib 2014) and the increasing competences of the EP in justice and home affairs under the ordinary legislative procedure since the Lisbon Treaty (Lavenex 2015), the immigration issue can be regarded as a crucial case for issue competition in the EP.

Since legislative agenda setting is primarily steered by the European Commission (Hix, Noury, and Roland 2007, 116), our focus lies on nonlegislative parliamentary instruments that play a role in issue competition (e.g., Green-Pedersen 2010; Proksch and Slapin 2011). Using an original data set measuring members of the European Parliament's (MEPs) issue emphasis through various types of parliamentary questions and motions spanning August 2004 to February 2016 on a weekly basis, we examine the leverage of radical right MEPs on European party groups (EPGs) dominated by national mainstream parties.

We find that European mainstream party groups decrease their weekly immigration emphasis in reaction to the radical right and, hence, do not find evidence for a positive contagion effect of radical right mobilization. This finding is robust to various estimation techniques and measurement methods. The results support the notion that both the electoral and the institutional context are key for dynamics of parliamentary issue competition - a conclusion that is important beyond the case of the EP. When institutional constraints minimize the electoral threat of niche parties, niche parties do not have the leverage they enjoy in electorally sensitive parliamentary contexts. In addition, the findings corroborate the supposition that parliamentary politics in the EP is dominated by the major party groups (Hix et al. 2007) leaving little room for direct or indirect influence by the smaller party groups.

\section{THEORY}

Saliency theory stipulates that a party's policy program is defined not solely by its position on a certain issue but also by which political issues it chooses to address in the first place (Baumgartner and Jones 2009; Budge and Farlie 1983; Carmines and Stimson 1986; Schattschneider 1960). Parties "own" different issues and try to develop a distinctive profile by emphasizing those issues (Petrocik 1996). The radical right's ownership of the "immigration issue" (Abou-Chadi2016), for instance, is so outspoken that many scholars refer to these parties exclusively as "anti-immigrant parties" (van der Brug, Fennema, and Tillie 2005).

Parties do not operate in a political vacuum, however. They respond to their political surroundings and engage in public debate over a great number of issues (Damore 2004; GreenPedersen and Mortensen 2010). Parties therefore do not have absolute control over their own issue agendas. Particularly in a competitive multiparty context, parties devise their issue attention strategies with an eye on their opponents in order to carve out a competitive advantage.

Moreover, not all types of political parties have equal strategic interest in politicizing issues previously ignored on the political agenda (Baumgartner and Jones 2009; Carmines and Stimson 1986). Mainstream parties that regularly hold office are not eager to radically transform the political agenda, as they tend to benefit from the status quo. Niche parties, by contrast, emphasize "noneconomic issues" largely ignored by their competitors (Meguid 2005; Wagner 2012a) and tend to benefit electorally from such "issue entrepreneurial strategies" (De Vries and Hobolt 2012). While quite a number of empirical studies focus on the extent to which mainstream parties respond to niche parties with positional shifts (Bale et al. 2010; Meijers 2017; van Spanje 2010), recent studies have focused on mainstream party responses to niche party agenda-setting efforts in terms of issue emphasis (AbouChadi 2016; Meijers and Rauh 2016; Spoon, Hobolt, and de Vries 2014; van de Wardt 2015).

Meguid $(2005,2008)$ has specified that mainstream parties may react to niche parties with an accommodative, an adversarial, or a dismissive strategy. Both the accommodative strategy, in which the niche party's position is adopted, and the adversarial strategy, in which the niche party's position is contested, convey an increase of issue emphasis. By contrast, a dismissive strategy signals that an issue lacks significance. While we conceptualize a dismissive strategy as indicating a decrease in issue emphasis (see Abou-Chadi 2016; van de Wardt 2015), others regard it as signifying either no increase in issue emphasis (Meguid 2005, 2008; see also Bale et al. 2010) or less issue emphasis in comparison to other parties or issues (Budge and Farlie 1983; Dolezal et al. 2014; Wagner 2012b).

The choice to engage with a niche party's issue is guided by electoral considerations (Green-Pedersen 2007; Meguid 2008). Mainstream parties' propensity to increase the emphasis of the niche party's issue depends, first, on the specific electoral threat the niche party poses (Meguid 2008, 99-103) and, second, on the extent to which the mainstream party considers the niche party issue to be a potential vote winner (Spoon et al. 2014). In this vein, studies on domestic issue competition over immigration policy have consistently found a positive "contagion effect" of radical right immigration issue emphasis on mainstream party emphasis (Abou-Chadi 2016; Harmel and Svasand 1997; van de Wardt 2015).

Crucially, this "electoral logic" of issue emphasis is not limited to the electoral arena but also applies to the parliamentary arena. Indeed, in most parliaments "legislative behavior is . . . shaped by the electoral contest" (Lindberg, 
Rasmussen, and Warntjen 2008, 1110). Mainstream and governing parties have been shown to respond to issue mobilization efforts of niche and opposition parties with increased emphasis of the issue in question (Green-Pedersen and Mortensen 2010; van de Wardt 2015; Vliegenthart et al. 2011). With respect to the immigration issue, van de Wardt (2015) has found that radical right niche parties affect the extent to which mainstream opposition parties address immigration issues in the Danish parliament.

Such issue engagement is usually costly in programmatic terms, as mainstream parties are forced to adopt a position on the issue, which is either a departure from their previous stance or in direct opposition to the niche party's position (Bale et al. 2010; Meguid 2008). By contrast, a dismissive strategy does not come at a great price. Therefore, only when the niche party poses a serious electoral threat to the relevant mainstream parties is it expected that mainstream parties will not pursue a dismissive strategy (Meguid 2008, 100).

Importantly, the extent to which niche parties pose a threat for mainstream parties is mediated by the electoral institutions in place (Meguid 2008, 97-99; Rohrschneider 1993). Mainstream party sensitivity to the niche party threat is mediated by the presence of electoral thresholds and disproportion of the vote-seat index. Accordingly, the argument we put forward in this article is in line with Meguid's reasoning that "strategic choices are sensitive to the setting in which they are made" $(2008,97)$. The next section elaborates on why we expect mainstream party groups in the EP to adopt a dismissive strategy in response to radical right immigration issue emphasis.

\section{Issue competition in the EP}

While studies of issue competition in the domestic context consistently found positive contagion effects of radical right mobilization on immigration policy, we expect issue competition dynamics to unfold differently in the EP for two reasons: politics in the EP is disconnected from its electoral arena(s) (Hix et al. 2007, 26), and the European Union's (EU) institutional structure has produced a relative dominance of the mainstream party families.

First, unlike the national parliamentary arena, the composition of the European parliamentary arena does not mirror the electoral arena. In most domestic legislatures, the "parliamentary game" is a continuation of the "electoral game" and vice versa (Green-Pedersen 2010; van de Wardt 2015; Vliegenthart et al. 2011). Yet, elections to the EP are held at the national level among domestic political parties - primarily decided on the basis of domestic issues and European integration issues (Hobolt, Spoon, and Tilley 2009; Reif and Schmitt 1980). Daily parliamentary affairs, however, are structured by EPGs (Rasmussen 2008, 1179) in which ideologically proximate national parties cooperate (McElroy and Benoit 2010).

As such, MEPs have two different principals (Hix 2002b). The national party selects candidates for EP elections. Party groups, however, provide indispensable political resources for MEPs between elections, such as their participation in parliamentary committees, which draft legislative reports and which receive speaking time in the plenary debates (Hix et al. 2007, 26). In fact, survey research among MEPs has found that EPGs principally regulate MEPs in day-to-day politics (Rasmussen 2008).

This produces the peculiar phenomenon of parliamentary politics without direct electoral repercussions, which likely affects patterns of parliamentary behavior. As Slapin and Proksch $(2010,336)$ note, "the electoral disconnection between European political groups and citizens raise[s] questions about the extent to which the parliamentary behavior of MEPs matters for re-election." As a result of the absence of such external motivations, "political behavior in the European Parliament is primarily driven by considerations internal to the institution and the EU policy process" (Hix et al. 2007, 28). A good example of this is that national competitors can be part of the same EPG, as is the case with the Dutch centerright People's Party for Freedom and Democracy (VVD) and social-liberal D66 parties - both of which are members of the liberal party group Alliance of Liberals and Democrats for Europe (ALDE).

With respect to issue competition, the lack of electoral repercussions of EP politics suggests that EP issue competition is less likely to be driven by electoral incentives. Hence, EP mainstream party groups have less to gain from increasingly emphasizing issues in response to niche parties, since the latter lack the electoral sway to present an imminent threat. Rather, mainstream party groups have an interest in keeping the issue agenda stable by defusing the niche party issue. While the electoral opportunity structure in the domestic context renders such a dismissive strategy rather risky (Bale et al. 2010; Meguid 2008, 99-103), party groups in the EP have greater maneuvering space to do so.

Also, the institutional peculiarities of EU policy making make a dismissive strategy of mainstream party groups in response to niche party emphasis in the EP more plausible. Legislative agenda setting in the European multilevel system is strongly dominated by political actors affiliated with Christian-democratic, social-democratic, and liberal parties linked to the European People's Party (EPP), Socialists and Democrats (S\&D), and ALDE, respectively (see Hix et al. $2007,114)$. Even though there is no evidence for purposive collusion across institutions and across party groups, there 
is a strong bias in the agenda-setting process toward centrist policies close to the political median.

In contrast to most domestic parliaments, the EP does not enjoy the right to initiate legislation. Instead, the commission proposes legislation, most of which must be passed by both the council and the EP since the introduction of the "ordinary legislative procedure" in the Lisbon Treaty. Although the commission is not steered by partisanship (Wonka 2008), it cannot be discounted that nearly all commissioners are career politicians stemming from the same Christian democratic and social democratic parties, and some are from liberal parties (see Hix 2005, 70). Moreover, the council is characterized by a rather centrist political profile, given that most governing parties representing their member states are affiliated with the EPP, S\&D, or ALDE.

In the EP, the EPP and S\&D have consistently constituted a majority and tend to dominate parliamentary affairs. In particular, the EP's internal agenda-setting processes are strongly dominated by the EPP and S\&D and, to a lesser extent, ALDE. Legislative agenda-setting offices, such as committee chairs and rapporteurships in the EP, are allocated roughly in proportion to party group size (Hix et al. 2007, 115). Moreover, because EP decision making increasingly occurs through fasttrack early agreements conducted in secluded meetings with representatives from the $\mathrm{EP}$, the council, and the commission (Yordanova 2016, 179), those actors affiliated with the larger mainstream party groups have more influence in such early agreement decision making (see Farrell and Héritier 2004).

The EPP, S\&D, and ALDE have an interest in upholding the status quo, with respect to both their extraordinary discretion in agenda setting and the specific issues that feature on the agenda. They have the incentive and the means to nip radical right issue mobilization attempts in the bud with a dismissive strategy on the immigration issue. Given the weak electoral linkage, moreover, the EPP, S\&D, and ALDE have the ability to do so as MEPs' parliamentary behavior seems of little consequence to the voter.

\section{The EP and immigration policy}

The scope condition for successful radical right issue entrepreneurship is that the EP is a relevant player in EU immigration policy. Exercising control over entry to and residence of migrants within the national territory touches on the es-

1. Also with respect to nonlegislative aspects of parliamentary activity in the EP, the three mainstream party groups have privileged agenda-setting opportunities. Many parliamentary instruments used for agenda setting, such as the tabling of motions, requesting hearings with the commission, and requesting parliamentary debates, are the exclusive prerogative of party groups or ad hoc coalitions of at least 40 MEPs. sence of national sovereignty (Lavenex 2015). Nevertheless, the dissolution of national borders in the Schengen Area required close coordination among EU member states on key questions such as immigration and asylum and border control. Over the years the EU has acquired significant competences over justice and home affairs (JHA) — often considered to be "core state powers" (Genschel and Jachtenfuchs 2016).

Before the Maastricht Treaty, a number of significant coordination efforts in directing European immigration and asylum policies produced intergovernmental agencies and treaties outside of the community framework (Lavenex 2015, 369-70). In 1992, the Maastricht Treaty incorporated many such intergovernmental treaties coordinating JHA policy into EU treaty law in the EU's intergovernmental "third pillar." The Treaty of Amsterdam of 1997 integrated the Schengen Convention into the treaties and formally placed migration policy in the first pillar - making migration questions to a certain extent subject to the supranational community method and empowering the EP through its role in the co-decision procedure from 2004 onward. ${ }^{2}$ With the Lisbon Treaty in 2009, the EP was granted full co-decision powers, as the ordinary legislative procedure was extended to all policy areas pertaining to JHA issues (Lavenex 2015, 369-73).

Hence, the power of the EP in migration policy has increased over the years (Hampshire 2015). As this arguably increases the prominence of the immigration issue on the EP's agenda, the extension of the EP's powers can affect issue competition on the migration issue as it increases mainstream party groups' incentive to adopt a dismissive strategy in reaction to radical right immigration emphasis. ${ }^{3}$

In line with the arguments related to mainstream dominance in EU institutions presented above, Lahav and Messina (2005), moreover, argue that there is an elite consensus on the immigration issue among MEPs — not subject to left-right contestation between the party groups. Given that political conflict in the EP primarily revolves around the left-right dimension and the EU integration dimension, mainstream party groups should have no incentive to emphasize immigration issues if external pressures are lacking (Hix 2001; Hix et al. 2007, 149; Otjes and van der Veer 2016; Roger, Otjes, and van der Veer 2017).

2. Denmark, Ireland, and the United Kingdom secured various optouts for the communitarization of JHA issues.

3. Nevertheless, most key competences on migration policy remain strongly in the hands of the member states' governments. As Lavenex (2015, 375 ) points out, the uneven structure of JHA policy at the EU level is testament to cautiousness of national governments with respect to supranationalization of core state tasks and has resulted in an unfinished, unsettled institutional framework (Luedtke 2009). 


\section{Hypothesis}

Combining insights from the issue competition literature and the literature on the electoral and institutional structures in the EP, we can formulate our central hypothesis. Both from an electoral perspective and an institutional perspective, EPGs likely adopt a dismissive strategy in response to radical party group mobilization on immigration policy. The issue competition literature has employed varying notions of the dismissive strategy, however. Bale et al. (2010) and Meguid $(2005,2008)$ conceptualize the dismissive strategy as nonaction, which presumably is analogous to a null hypothesis. Others consider the dismissive strategy to denote a party's lesser degree of issue emphasis vis-à-vis its competitorshypothesizing differences across parties (Dolezal et al. 2014; Wagner 2012b). This article regards a dismissive strategy to signify a decrease in a party's issue emphasis in comparison to previous points in time (see also Abou-Chadi 2016; van de Wardt 2015) — permitting a directional hypothesis test. Consequently, considering the EP's lack of electoral opportunity structure and mainstream party groups' interest in upholding their institutional dominance in the EU, our central hypothesis states:

Dismissive Strategy Hypothesis The more radical right MEPs emphasize the immigration issue at $t-1$, the less mainstream party groups emphasize the immigration issue at time $t$.

\section{DATA AND METHOD: ANALYZING ISSUE COMPETITION IN THE EP}

We study issue competition in the EP through MEPs' issue mobilization attempts with nonlegislative parliamentary instruments. By contrast, studies of EP agenda setting have often focused on the role of rapporteurs in shaping the formal agenda (Finke 2012, 2015; Thierse 2019). ${ }^{4}$ Once the commission has proposed a draft bill under the ordinary legislative procedure, the Conference of Presidents (CoP) appoints the relevant standing committee, which in turn assigns the bill a rapporteur. The rapporteur evaluates the bill and adopts a position on it and proposes amendments if deemed necessary. Before the draft bill (with or without amendments) is put to a plenary vote in the $\mathrm{EP}$, the committee votes on and

4. Scholarship on agenda setting in the EP context has focused on different emanations of agenda setting. Hix has regarded the extension of the EP powers in the Amsterdam Treaty as the result of the EP's "constitutional agenda-setting" powers (Hix 2002a). Tsebelis (1994) regarded the EP's ability to incentivize the council to accept amendment proposals as an indication of its agenda-setting powers. Others study voting patterns in the EP on an agenda that is exogenously set by the commission and council (Blumenau and Lauderdale 2018; see Otjes and van der Veer [2016] for similar findings). amends the report. While the rapporteur has some leeway in framing the bill's policy issue (Thierse 2019), the rapporteur ultimately is responsible for adopting a position on the bill proposed by the commission (Hix et al. 2007, 113). Hence, while rapporteurs are undoubtedly crucial players in the EU's policy process, they have very limited scope to introduce new issues on the agenda. ${ }^{5}$ In other words, rapporteurships and committee memberships are not viable venues for MEPs' strategic issue emphasis.

In addition, the EP's plenary agenda is determined by the CoP, consisting of the EP president and the chairs of all party groups, which usually operates on the basis of consensus (Corbett, Jacobs, and Shackleton 2011). Apart from organizing the day-to-day order of affairs, $\mathrm{CoP}$ members also draft the agenda for the part sessions in which they can choose to address certain issues. Yet, the plenary agenda is also not relevant to studying issue competition, as the party groups cannot choose single-handedly which issues will appear on the agenda - the agenda is a compromise between multiple actors. Moreover, it is not possible to ascertain which actor in the $\mathrm{CoP}$ drives which agenda choice, given that the CoP meets behind closed doors. ${ }^{6}$

In order to assess the dynamics of issue competition in the EP, we therefore examine MEPs' attempts to raise attention to the immigration issue with nonlegislative parliamentary instruments (Proksch and Slapin 2011). We primarily focus on written and written priority parliamentary questions. Parliamentary questions are particularly useful for issue mobilization purposes, as it is the parliamentary tool least affected by the disproportionate institutional constraints in the EP. ${ }^{7}$ Parliamentary questions do not only offer a powerful instrument to political groups in opposition for executive oversight (Proksch and Slapin 2011), but they are also important for issue competition for both mainstream and nonmainstream actors (Green-Pedersen and Mortensen 2010; Vliegenthart et al. 2011). ${ }^{8}$

5. So-called own initiative reports are an exception, as committees are free to select the subject. Nevertheless, own initiative reports formally also require the consent of the $\mathrm{CoP}$.

6. A semiautomated content analysis on the keyword "migration," moreover, shows that throughout EP 6 (2004-9) and EP 7 (2009-14) migration appeared on the agenda only 22 times out of ca. 400 plenary days. This suggests that, if anything, the CoP adopts a dismissive strategy on the immigration issue.

7. Other nonlegislative parliamentary instruments, such as speeches and the tabling of motions, face greater institutional constraints. Given that most speeches are to be held on an issue previously determined by the CoP makes it a less effective tool for issue competition.

8. MEPs can pose four types of parliamentary questions: ordinary parliamentary questions, priority written questions, questions for question time prior to a legislative debate, and questions with an oral answer and debate. Our 


\section{Data}

Our empirical focus lies on the emphasis of the immigration issue by MEPs through parliamentary questions during the period between August 2004 and February 2016, spanning two full EP terms (the sixth term from 2004 to 2009 and the seventh term from 2009 to 2014) and the first one and a half years of the eighth term. The primary analysis relies on an original data set of virtually all parliamentary records combined with data on the party group and national party affiliation of the MEP in question.

This data set is constructed by automated scraping and normalization of disaggregated data from the online parliamentary archives. After structuring the parliamentary records, we linked them to stable identifiers for legislators, parties, and EPGs. The full data set of written and priority written parliamentary questions amounts to 122,041 questions, 11,347 of which were related to the immigration issue. Radical right MEPs asked 2,792 immigration-related questions, and MEPs from the mainstream party groups asked a total of 4,393 questions.

Questions asked by MEPs whose national party is affiliated with the EPP, S\&D, or ALDE are coded as "mainstream party group questions" since their constituent national parties often take part in national office (Hix et al. 2007, 116). Table A1 (tables A1-A10 are available online) shows that the absolute number as well as proportion of national parties in government within the EPP, S\&D, and ALDE is much higher.

Whereas mainstream parties are aligned in party groups, not all radical right parties have been able to form stable party groups (McDonnell and Werner 2018). Although a number of radical right party groups exist or have existed, many radical right MEPs are aligned with an informal technical group of nonattached members. This nonattached group, however, also contains Far Left oriented MEPs. Therefore, "radical right questions" are coded on the basis of whether the MEP's national party belongs to the radical right party family. Radical right parties are defined in accordance with Mudde (2007). ${ }^{9}$ To examine whether mainstream party groups respond differently to radical right emphasis than other party groups, we have additionally collected data for the party groups without radical right members; the radical left party group European United Left/Nordic Green Left (GUE/NGL) and the Green party group. Figure 1 shows the number of MEPs per

principal analysis is restricted to ordinary parliamentary questions and priority written questions, since other types of parliamentary questions face greater institutional constraints, as the opportunity to successfully table them hinges on acceptance of these questions by the EP president and the CoP.

9. The appendix, available online, provides for a full list of national parties considered to be radical right. party group and the share of radical right MEPs. On average, $8 \%$ of MEPs are radical right MEPs, and $7 \%$ of the national parties in the EP belong to the radical right.

Whether a parliamentary question concerns immigration policy is established by means of a semiautomated content analysis on the basis of a dictionary of keywords pertaining to the immigration issue on the EU level. This list of keywords is designed to appropriately cover both radical right and mainstream party discourse on immigration on the EU level. ${ }^{10}$ The descriptive analysis of keyword usage in table A3b shows that most party groups use similar keywords referring to immigration. Yet, the radical right uses keywords related to "Islam" more and keywords related to "refugees" less than other party groups.

\section{Estimation method}

In order to examine whether radical right immigration emphasis affects mainstream party groups' emphasis of the issue, we examine issue competition dynamics within various time structures. Usually, issue competition dynamics are measured with extended time brackets of multiple years (De Vries and Hobolt 2012), election years (Abou-Chadi 2016; Meguid 2008; Spoon et al. 2014), or calendar years (Green-Pedersen 2007; Green-Pedersen and Mortensen 2010; van de Wardt 2015). Yet, Vliegenthart et al. (2011) have argued that such an approach does not do justice to fast-changing complexities of issue competition in the parliamentary arena. Rather, in an attempt to shape the agenda, parties are shown to also engage in short-term issue competition (e.g., Meijers and Rauh 2016).

Following the study by Vliegenthart et al. (2011) of the Belgian parliament, we therefore primarily focus on the weekly issue competition dynamics in the EP in a time-series crosssectional design. Given that mainstream actors' response to niche parties can also occur in more extended time brackets, we model the monthly and quarterly effects of radical emphasis on mainstream parties' agendas as a robustness test. This is important, as the time period in which parties and party groups are expected to react to one another is undertheorized.

Hence, the main unit of analysis is the change in the number of parliamentary questions on immigration posed per mainstream party group per week - with the mainstream party group as cross-section identifier. In other words, the dependent variable is the first difference of mainstream party group

10. Keywords for mainstream party EU migration discourse were informed by Lavenex's (2015) chapter on JHA. Keywords for radical right immigration discourse were created with reference to existing political communication studies on immigration (Boomgaarden and Vliegenthart 2007). The full list of keywords is presented in table A3a. 


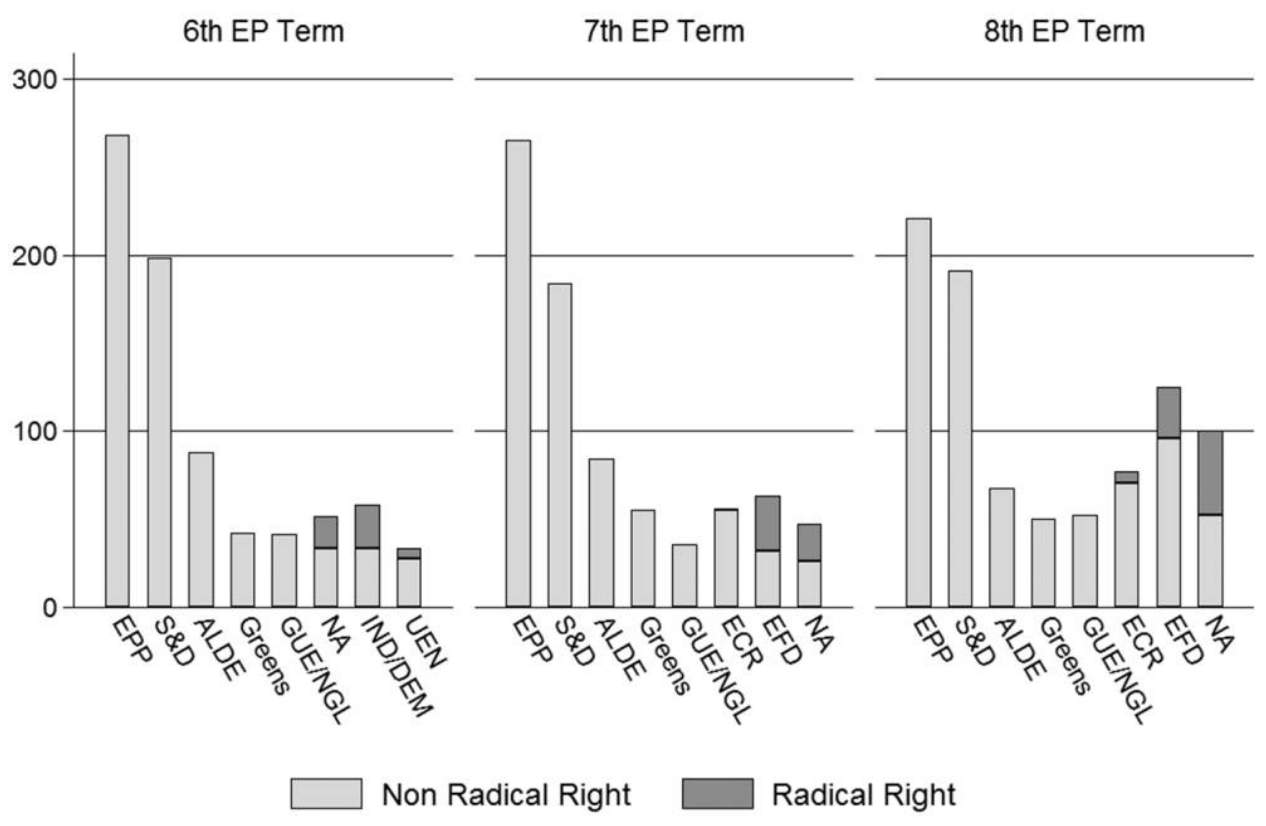

Figure 1. Number of MEPs per party group (measured at the start of each legislative term) and the share of radical right MEPs in each party group

emphasis representing the change in emphasis of immigration compared to the week before. The main independent variable is also first-differenced and measures the weekly change of radical right immigration emphasis lagged by one time period. ${ }^{11}$ With this first-differenced measurement, we capture the dynamic effects of radical right issue emphasis from week to week on mainstream parties' emphasis of immigration policy. ${ }^{12}$ Table A4a shows the summary statistics of the main variables for the weekly party group models. ${ }^{13}$

In order to examine whether radical right emphasis of the immigration issue spurs a response of mainstream party groups, we calculate pooled ordinary least squares regression models with a Prais-Winsten transformation with a panelspecific first-order autoregression, $\operatorname{AR}(1)$, error structure to account for serial correlation. Other studies have relied on a lagged dependent variable to account for autocorrelation, but recent research has shown that this could lead to bias related to trends in the error term (Plümper, Troeger, and Manow 2005). We include party group fixed effects by inserting party group dummies in the model, as this is essential for making causal claims about radical right issue emphasis on the mainstream party group issue agenda (Abou-Chadi 2016). The

11. While we think a lag of one week reflects the dynamics of parliamentary behavior best, we do not exclude the possibility that further lags could affect mainstream EPG's immigration emphasis. Therefore, table A5 shows the estimates for further and multiple lags.

12. The weekly time structure of the data ensures that the models account for long- and medium-term contextual changes.

13. Summary statistics for other operationalizations can be found in tables A4b-A4d. party group dummies also control for the direct and conditional effect of party group membership and examine whether some party groups are more responsive to the radical right than others.

To account for the possibility that mainstream party groups react to one another, we include the lagged first differenced attention to immigration issues by the other mainstream parties. In addition, we control for the direct and conditional effect of EP terms for two reasons. First, with the enactment of the Lisbon Treaty in December 2009, almost all JHA issues related to immigration became subject to the ordinary legislative procedure-significantly empowering the EP (Hampshire 2015). This can affect the incentives for mainstream party group issue emphasis. Second, given that the radical right increased its seat share considerably in the 2014 EP elections (Treib 2014), the dynamics of issue competition in the EP can be affected by the EP's composition. This amounts to the following basic model in which the sixth EP term dummy and the ALDE party group dummy serve as baseline variables:

$$
\begin{aligned}
& \Delta \text { mainstream EPG emphasis }_{i, t} \\
& \begin{aligned}
=\beta_{0} & +\beta_{1}\left(\Delta \text { radical right emphasis }_{i, t-1}\right) \\
& +\beta_{2}\left(\Delta \text { other mainstream EPG emphasis }_{i, t-1}\right) \\
& +\beta_{3}\left(\text { EP term } 7 \text { dummy }_{i, t}\right)+\beta_{4}\left({\text { EP term } \left.8 \text { dummy }_{i, t}\right)}+\beta_{5}\left(\text { EPP dummy }_{i, t}\right)+\beta_{6}\left(\mathrm{~S} \& \mathrm{D} \text { dummy }_{i, t}\right)+v_{i, t}+\varepsilon_{i, t} .\right.
\end{aligned}
\end{aligned}
$$

Although we primarily focus on written parliamentary questions, it is nevertheless possible that mainstream party groups 
engage in issue competition using other nonlegislative parliamentary instruments, as they do not face the same institutional constraints radical right MEPs face. To account for this in the empirical design, we include an alternative dependent variable as a robustness test with all relevant nonlegislative parliamentary instruments, by adding oral parliamentary questions, preannouncement of questions at question time, and motions for resolutions.

Following other studies of parliamentary issue competition (Green-Pedersen and Mortensen 2010; van de Wardt 2015; Vliegenthart et al. 2011), we expect mainstream party groups to engage in issue emphasis strategies as cohesive actors. Yet, given that party switching between different EPGs occurs (McElroy and Benoit 2010), it is possible that MEPs are not guided by their party groups or national parties but engage in issue emphasis strategies at their own discretion. Therefore, we also calculate a model on the level of the individual MEPs as a robustness test. We constructed our MEP-level data set by generating observations on a week-by-week basis for all nonradical right MEPs who have asked a parliamentary question in the analyzed week mentioning immigration. The dependent variable is a dichotomous variable measuring whether an MEP emphasized the immigration issue or not. The independent variable measures the total number of immigrationrelated parliamentary questions asked by the radical right in the previous week. To account for individual MEP characteristics, we calculate a fixed effects logistic panel regression model with an additional EP term and party group fixed effects.

\section{RESULTS}

Figure 2 shows the proportion of written and written priority parliamentary questions by party group related to the

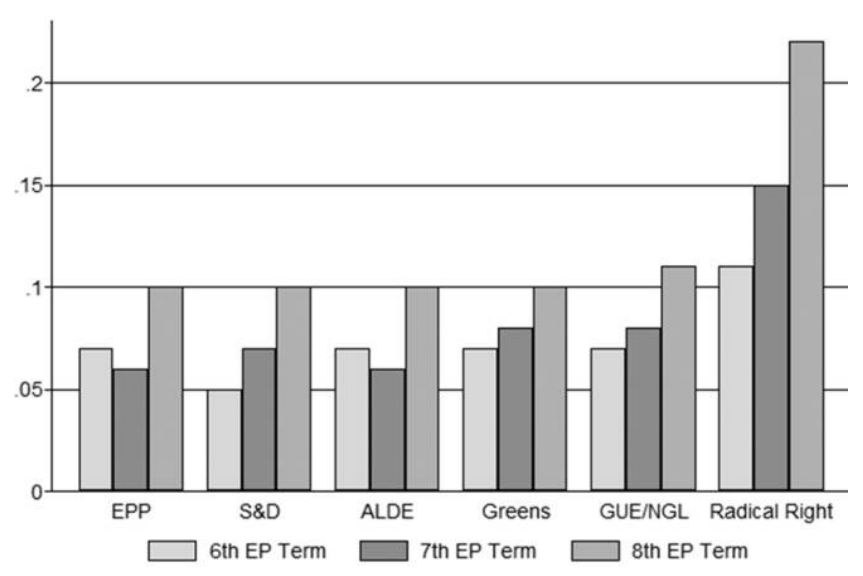

Figure 2. Relative share of immigration-related written and priority written parliamentary questions by party group relative to the total amount of parliamentary questions for the sixth, seventh, and eighth EP. $N=96,084$ (total number of written and priority written parliamentary questions by the selected party groups and MEP types). immigration issue, relative to the total number of questions asked for the sixth, seventh, and eighth EP (until February 2016). Figure 2 shows that the radical right is indeed the "owner" of the immigration issue in the EP. Mainstream party groups as well as the Green party group and the radical left party group GUE/NGL emphasize the issue less in comparison to other issues. While the relative salience of the immigration issue in the EP was stable before 2014, all party groups have increased their share of immigration emphasis in the eighth EP. Given the unprecedented increase in the number of refugees in EU member states because of violent conflict in nearby regions (Trauner 2016), this increase is not surprising. It is important to note, however, that the radical right's immigration emphasis remained approximately twice as strong as the other party groups throughout the period. Moreover, our central hypothesis formulated the expectation that mainstream parties adopt a dismissive strategy on the immigration issue in response to the radical right. As such, we expect that this increase in immigration emphasis post-2014 is not caused by the radical right's issue emphasis.

The time-series cross-sectional analysis presented in table 1 tests the central hypothesis that radical right MEPs motivate mainstream party groups to emphasize the immigration issue less. Table 1 demonstrates that radical right emphasis change has a statistically significant negative effect on the weekly change in emphasis of immigration issues by mainstream parliamentary groups. This effect is small in substantive terms, however. The finding that the increase of immigration issue emphasis by radical right MEPs motivates mainstream party groups to lower their attention to the immigration issue allows us to accept our central hypothesisnotwithstanding the substantively small effect size. Contrary to what is usually found in the domestic context, this therefore confirms the expectation that increased radical right immigration emphasis in the EP does not lead to a positive change in mainstream party emphasis of the immigration issue.

Based on a model measuring the interaction between the party group dummy and change of radical right immigration emphasis, the marginal effects plot in figure 3 presents the predicted value of the dependent variable for different values of radical right emphasis change per party group - as is common practice when estimating conditional effects (Brambor, Clark, and Golder 2006). ${ }^{14}$ In order to compare mainstream party groups with nonmainstream parties, the estimates for the Green party group and the radical left party group GUE/ NGL are also shown. Figure 3 shows that there is a significant negative effect of radical right emphasis on the issue empha-

14. The model with the interactions on which figs. 3 and 4 are calculated can be found in table A5. 
Table 1. Pooled Time Series Regression Model of Mainstream EPG's Weekly Change in Immigration Emphasis

Model 1

$\Delta$ Mainstream EPG

Weekly Emphasis

$\begin{array}{lc}\Delta \text { radical right emphasis }(t-1) & -.0833^{* * *} \\ & (.0196) \\ \Delta \text { other mainstream EPG emphasis }(t-1) & -.0262 \\ & (.0178) \\ \text { European People's Party } & .0193 \\ & (.112) \\ \text { Socialists and Democrats } & .0250 \\ & (.0873) \\ \text { European Parliament } 7 & .0844 \\ & (.303) \\ \text { European Parliament } 8 & .353 \\ & (.488) \\ \text { Time } & -.000334 \\ & (.00102) \\ \text { Constant } & .0296 \\ N & (.165) \\ & 1,803\end{array}$

Note. Prais-Winsten regression coefficients with panel-corrected standard errors in parentheses. EPG = European party group.

${ }^{*} p<.05$.

${ }^{* *} p<.01$.

${ }^{* * *} p<.001$.

sis of the mainstream party groups ALDE, EPP, and S\&D but not on the immigration emphasis of the green and radical left party group. Moreover, the slope of the marginal effects plot for the EPP and S\&D is slightly steeper than for ALDE, suggesting a more pronounced negative effect.

\section{ROBUSTNESS OF THE RESULTS}

Crucially, our findings are robust to various model specifications, different time structures, and alternative measurement methods. Table A6 shows that this finding also holds when multiple lags are introduced. Moreover, vector autoregression analysis accompanied by cumulative impulse response function graphs display a similar result (see tables A7a and A7b and fig. A2; figs. A1-A4 are available online). In addition, in order to make sure that the significant negative effect of radical right emphasis is particular to the immigration issue and not the function of an agenda cycle, we conducted placebo tests with another issue, the environment. The results in table $\mathrm{A} 8 \mathrm{~b}$ indicate that the radical right emphasis of the environmental issue has no statistically significant impact on mainstream environment emphasis, which further augments the confidence in our results.
It is conceivable that time- and EP-term-dependent factors influence our results. Therefore, we have additionally examined the conditional effect of the EP term on the effect of radical right immigration emphasis on mainstream party emphasis as shown in figure 4 . We find that the negative effect of radical right immigration emphasis on mainstream party group emphasis change is more pronounced in the seventh EP term than in the sixth EP term. ${ }^{15}$ The negative effect in the eighth EP term - compared to the seventh EP term - was even more pronounced. As the greater effect size also indicates, these findings suggest that as the salience of the immigration issue increases over time, as figure 1 has shown, the size of the negative effect of radical right emphasis increases. ${ }^{16}$ The finding that mainstream parties respond stronger to radical right MEPs' immigration emphasis in times when in the immigration issue becomes more salient provides additional evidence for the hypothesis that mainstream party groups attempt to de-emphasize the immigration issue in response to the radical right when they have the ability to do so.

As it is theoretically possible that mainstream party groups choose to respond to the radical right using other parliamentary instruments, we calculated weekly models that allowed for the possibility that both radical right and mainstream MEPs use additional instruments including oral parliamentary questions, preannouncements of questions at question time, and motions (model 1 in table 2). Nevertheless, this analysis yields substantively similar results. The fact that the inclusion of motions and other types of parliamentary questions does not affect the results lends further credence to their robustness and suggests that - as expected - these other nonlegislative parliamentary instruments are not relevant for parliamentary issue competition in the EP.

Additionally, we have conducted a robustness test for the possibility that radical right MEPs induce more immigration emphasis within larger time brackets. In table 2, we report analyses based on monthly and quarterly data in models 2 and 3, respectively. In the monthly and quarterly analyses, we no longer find a significant negative effect of radical right immigration emphasis. Yet, the statistically insignificant estimates suggest that there is no positive effect of radical right emphasis on mainstream immigration emphasis. ${ }^{17}$ Given that

15. The difference between the sixth and the seventh EP is borderline significant at an alpha of 0.05 .

16. Additionally, we have calculated the marginal effects of radical right emphasis change for a linear (fig. A3a) and a quadratic (fig. A3b) continuous time variable. Substantively, these estimates show the same result. Yet, they indicate that there is no significant negative effect of radical right emphasis change on mainstream party groups before the seventh EP term.

17. The marginal effects plots per party group for the aggregated monthly and quarterly analyses in the appendix corroborate this. 

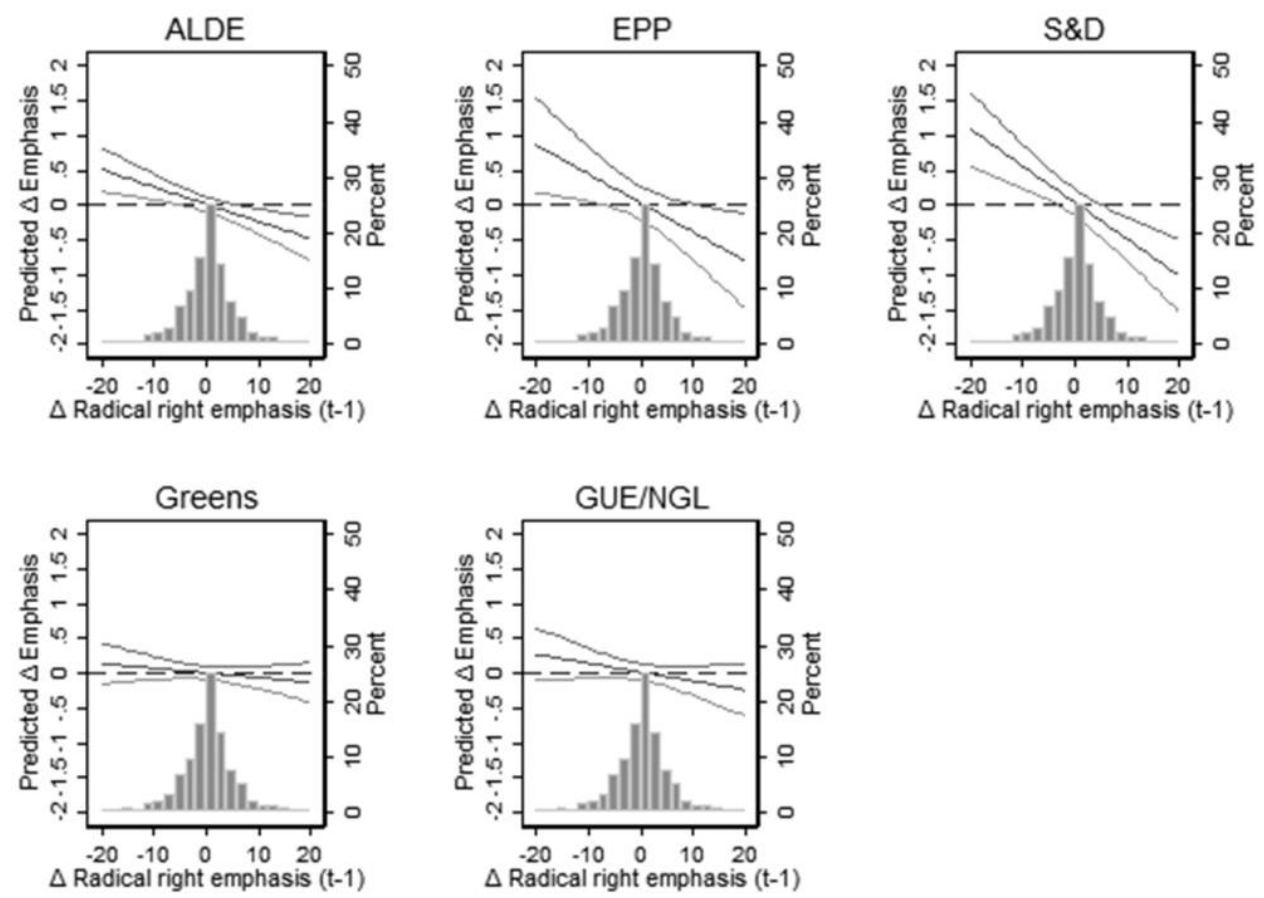

Figure 3. Marginal effect of a change in radical right immigration issue emphasis at $t-1$ on the predicted change of mainstream party group emphasis of the immigration issue per party group. Rug plot presents the distribution of the variable $\Delta$ radical right emphasis $(t-1)$.

a dismissive strategy has been conceptualized not only as a decrease in emphasis but also as a lack of response in emphasis (see Meguid 2005), the results of the monthly and quarterly analyses suggest a dismissive response à la Meguid. However, since the absence of statistically significant effects offers weak evidence for the actual absence of a relationship (Gill 1999; Rainey 2014), additional evidence specifying the absence of meaningful effects strengthens arguments for the absence of an effect (Rainey 2014). The coefficient plots in figures A5a and A5b indicate that the insignificant effect is also a substantively negligible effect. ${ }^{18}$ The absence of a substantively meaningful positive effect increases our confidence that mainstream party groups do not increase their emphasis in reaction to the radical right in the monthly and quarterly time periods.

The previous models on party group level data are based on the implicit assumption that EPGs largely function as cohesive actors. The occurrence of party switching between different EPGs suggests, however, that MEPs are possibly not steered by their respective party groups (McElroy and Benoit 2010). As a robustness check, we therefore examine whether the result also holds with MEP-level data with a fixed effects logistic panel regression model (table A10). The statistically significant, negative coefficient displays a similar effect for

18. The definition and measurement of meaningful effects is discussed in the appendix. the MEP-level data. This bolsters our confidence in the party group level results and serves as additional evidence that party groups are cohesive agenda setters in the EP (Rasmussen 2008). To be sure, such party group cohesion does not prove that unity is a function of party groups' ability to enforce MEP loyalty rather than a product of converging MEP preferences (see Krehbiel 1993; Willumsen and Öhberg 2017). For the purpose of our theoretical argument, however, the strong convergence of the party group level and the MEP-level results is sufficient evidence that our party group level analy-
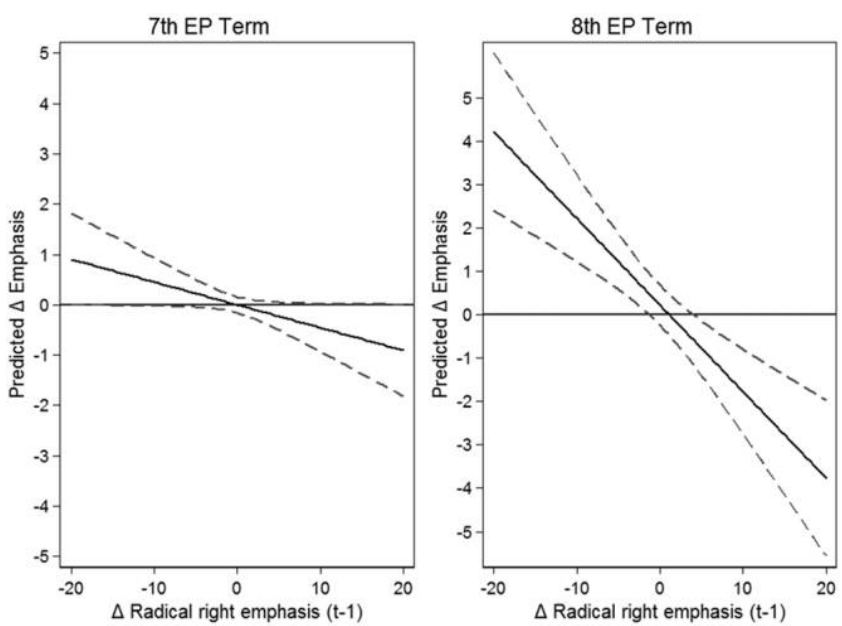

Figure 4. Marginal effect of a change in radical right immigration issue emphasis at $t-1$ on the predicted change of mainstream party group emphasis between EP 6 and EP 7 (left) and EP 7 and EP 8 (right). 
Table 2. Alternative Specifications of the Pooled Time Series Regression Model of Mainstream EPG's Change in Immigration Emphasis

\begin{tabular}{|c|c|c|c|}
\hline & $\begin{array}{c}\text { Model } 1 \\
\Delta \text { Mainstream EPG Weekly } \\
\text { Emphasis (All Instruments) }\end{array}$ & $\begin{array}{c}\text { Model } 2 \\
\Delta \text { Mainstream EPG } \\
\text { Monthly Emphasis }\end{array}$ & $\begin{array}{c}\text { Model } 3 \\
\Delta \text { Mainstream EPG } \\
\text { Quarterly Emphasis }\end{array}$ \\
\hline$\Delta$ radical right emphasis $(t-1)$ & $\begin{array}{c}-.0789^{* *} \\
(.0286)\end{array}$ & $\begin{array}{l}.0189 \\
(.0528)\end{array}$ & $\begin{array}{c}-.0843 \\
(.0817)\end{array}$ \\
\hline$\Delta$ other mainstream EPG emphasis $(t-1)$ & $\begin{array}{r}-.0356 \\
(.0235)\end{array}$ & $\begin{array}{c}.0164 \\
(.0485)\end{array}$ & $\begin{array}{c}-.0419 \\
(.0766)\end{array}$ \\
\hline European People's Party & $\begin{array}{l}.0182 \\
(.128)\end{array}$ & $\begin{array}{l}.0821 \\
(.162)\end{array}$ & $\begin{array}{l}.126 \\
(.173)\end{array}$ \\
\hline Socialists and Democrats & $\begin{array}{l}.0229 \\
(.100)\end{array}$ & $\begin{array}{l}.114 \\
(.134)\end{array}$ & $\begin{array}{l}.134 \\
(.139)\end{array}$ \\
\hline European Parliament 7 & $\begin{array}{l}.160 \\
(.510)\end{array}$ & $\begin{array}{l}.196 \\
(.502)\end{array}$ & $\begin{array}{c}.922 \\
(.556)\end{array}$ \\
\hline European Parliament 8 & $\begin{array}{c}.524 \\
(.820)\end{array}$ & $\begin{array}{l}1.141 \\
(.814)\end{array}$ & $\begin{array}{l}2.369^{* *} \\
(.907)\end{array}$ \\
\hline Time & $\begin{array}{r}-.000635 \\
(.00171)\end{array}$ & $\begin{array}{c}-.00291 \\
(.00737)\end{array}$ & $\begin{array}{c}-.0392 \\
(.0247)\end{array}$ \\
\hline Constant & $\begin{array}{l}.0706 \\
(.286)\end{array}$ & $\begin{array}{l}.0215 \\
(.284)\end{array}$ & $\begin{array}{c}.347 \\
(.346)\end{array}$ \\
\hline$N$ & 1,803 & 414 & 138 \\
\hline
\end{tabular}

Note. Prais-Winsten regression coefficients with panel-corrected standard errors in parentheses. EPG $=$ European party group.

${ }^{*} p<.05$.

$* * p<.01$.

${ }^{* * *} p<.001$

sis is not the product of "artificial" aggregation. All in all, our central hypothesis, which formulated the expectation that radical right issue emphasis change on the immigration issue negatively affects the propensity of mainstream party groups to address the issue, can be accepted.

\section{CONCLUSION}

The issue competition literature argues that the leverage of niche parties, such as the radical right, over mainstream policy agendas hinges on the potential electoral threat the niche party poses to the mainstream party (Green-Pedersen 2007; Meguid 2008). Relying on an original data set of immigrationrelated parliamentary questions posed by MEPs between 2004 and 2016, we examined the case of immigration issue emphasis in the EP - an institutional setting in which niche party actors lack electoral leverage over mainstream actors and face particular institutional disadvantages vis-à-vis their mainstream competitors. We show that the lack of a strong electoral connection in the EP and the disproportionate institutional power in the EP creates a condition in which mainstream party groups do not respond to increased radical right immigration emphasis with increased immigration emphasis. Rather, dynamic week-by-week analyses demonstrated that our hypothesis that mainstream party groups tone down the emphasis of the immigration issue in response to radical right emphasis can be accepted. This corroborates other findings of short-term party issue competition (Hopmann et al. 2012; Meijers and Rauh 2016; Vliegenthart et al. 2011). The monthly and quarterly analyses moreover found no meaningful positive effect of radical right mobilization in the EP indicating that mainstream party groups do not increase their emphasis of the immigration issue in response to the radical right.

This pattern deviates considerably with the patterns found in the national electoral arena. National-level studies have shown that mainstream parties increase the emphasis of the immigration issue in response to the mobilization of the immigration issue by radical right parties (Abou-Chadi 2016; Harmel and Svasand 1997; van de Wardt 2015). Our findings therefore suggest that institutional opportunity structures shaping the niche party actors' threat potential are crucial for our understanding of issue emphasis of mainstream parties in response to radical right challengers. This conclusion is in line with the idea that electoral rules and parliamentary rules have a strong influence on the dynamic interaction between niche party actors and mainstream party actors 
(Karp and Banducci 2002; Meguid 2008, 97-99; Rohrschneider 1993). Future research should further explore how electoral institutions and parliamentary procedural rules affect issue competition dynamics - also in the domestic context.

The contrasting findings in the weekly analysis and the monthly and quarterly analyses moreover highlight conceptual ambiguity with respect to dismissive and de-emphasizing strategies. So far, the literature has not been clear about the different manifestations of dismissive strategies. To some, a dismissive strategy refers to nonaction (Bale et al. 2010; Carmines and Stimson 1986; Meguid 2008); others regard a dismissive strategy to denote a low degree of issue emphasis relative to other competitors (Dolezal et al. 2014; Wagner 2012b), to other issues (Budge and Farlie 1983; Volkens et al. 2013), or to previous points in time (Abou-Chadi 2016; van de Wardt 2015). Scholars of issue competition are therefore well advised to clarify conceptually what they measure and, accordingly, reflect on that in theoretical terms.

This article has focused on issue competition through nonlegislative parliamentary instruments in the EP. Our results are robust to the inclusion of various parliamentary instruments. Parliamentary activities by parliamentary committees and rapporteurs are not included in the analysis, as we argue that these venues do not give MEPs the opportunity to strategically emphasize certain policy issues. Our empirical focus on a single political arena is moreover in line with virtually all studies of issue competition focusing either on the electoral setting (Abou-Chadi 2016; Budge and Farlie 1983; De Vries and Hobolt 2012; Meguid 2005) or on the parliamentary setting (Green-Pedersen 2010; Green-Pedersen and Mortensen 2010; Proksch and Slapin 2011; Vliegenthart et al. 2011). Integrating different political arenas with distinct institutional dynamics in a single explanatory model of party competition nevertheless remains a task for the discipline- - both in the national and in the EU context.

In all likelihood the issue of immigration will stay and become even more important with the rising number of immigrants coming to the EU (Trauner 2016). At the same time, the progression toward an "ever-closer Union" has come under attack, not only by Eurosceptic parties on the fringes of the political spectrum but also from mainstream parties (Meijers 2017). In the United Kingdom, the immigration issue was a key factor in the Brexit referendum to leave the EU in June 2016 (Hobolt 2016). Moreover, in many respects the formal competences on migration policy still reside with the member states and the introduction of the Early Warning Mechanism since the Lisbon Treaty has increasingly empowered national parliaments to steer EU legislation (Cooper 2012). The nationalization of immigration policy could lead to a further decoupling of the EP's electoral and parliamentary arena, giving mainstream EPGs even more leeway to de-emphasize immigration policy in the EP. Our results suggest that this might be the case. The increase in immigration salience in the EP since the eighth EP term, on the one hand, and the stronger deemphasizing response of mainstream party groups to the radical right in the eighth EP term, on the other hand, imply that mainstream party groups can afford to be unresponsive to political competitors when shielded from electoral competition.

Yet, the surge in the number of refugees has forced the EU to act cohesively - as the contentious EU-Turkey agreement of March 2016 demonstrates. Supranational solutions to the migration issue can increase the importance of immigration policy in the EP-as the increasing salience of the immigration issue in the EP since mid-2014 suggests. Therefore, the political reality of the increase of migrants from war-stricken regions seems to do what the radical right has been unable to do: to change the political agenda mainstream party groups have tried to carefully control.

\section{ACKNOWLEDGMENTS}

We would like to thank the four anonymous reviewers and JOP's editors for their insightful comments. We would also like to thank participants of the Quantitative Methods Seminar at the University of Amsterdam, the Radboud University PoliSci Seminar, the 23rd International Conference of Europeanists in Philadelphia, the Politicologenetmaal 2016 in Brussels, and the Conference of the European Consortium for Political Research (ECPR) Standing Group on Parliaments 2016 in Munich. The article also benefited from feedback from Arndt Leininger, Simon Otjes, Tom van der Meer, Eelco Harteveld, Gijs Schumacher, Remko Voogd, and Hannah Werner.

\section{REFERENCES}

Abou-Chadi, Tarik. 2016. "Niche Party Success and Mainstream Party Policy Shifts: How Green and Far-Right Parties Differ in Their Impact." British Journal of Political Science 46 (2): 417-36.

Bale, Tim, Christoffer Green-Pedersen, André Krouwel, Kurt Richard Luther, and Nick Sitter. 2010. "If You Can't Beat Them, Join Them? Explaining Social Democratic Responses to the Challenge from the Populist Radical Right in Western Europe." Political Studies 58 (3): 410-26.

Baumgartner, Frank R., and Bryan D. Jones. 2009. Agendas and Instability in American Politics. 2nd ed. Chicago: University of Chicago Press.

Blumenau, Jack, and Benjamin E. Lauderdale. 2018. "Never Let a Good Crisis Go to Waste: Agenda Setting and Legislative Voting in Response to the EU Crisis." Lournal of Politics 80 (2): 462-78.

Boomgaarden, Hajo G., and Rens Vliegenthart. 2007. "Explaining the Rise of Anti-immigrant Parties: The Role of News Media Content." Electoral Studies 26 (2): 404-17.

Brambor, Thomas, William Roberts Clark, and Matt Golder. 2006. "Understanding Interaction Models: Improving Empirical Analyses.” Political Analysis 14 (1): 63-82.

Budge, Ian, and Dennis Farlie. 1983. "Party Competition: Selective Emphasis or Direct Confrontation?” In Hans Daalder and Peter Mair, eds., 
Western European Party Systems: Continuity and Change. London: Sage, 267-306.

Carmines, Edward G., and James A. Stimson. 1986. "On the Structure and Sequence of Issue Evolution.” American Political Science Review 80 (3): 901-20.

Cooper, Ian. 2012. “A 'Virtual Third Chamber' for the European Union? National Parliaments after the Treaty of Lisbon." West European Politics 35 (3): 441-65.

Corbett, Richard, Francis Jacobs, and Michael Shackleton. 2011. The European Parliament. 8th ed. London: Harper.

Damore, David F. 2004. "The Dynamics of Issue Ownership in Presidential Campaigns.” Political Research Quarterly 57 (3): 391-97.

De Vries, Catherine E., and Sara B. Hobolt. 2012. "When Dimensions Collide: The Electoral Success of Issue Entrepreneurs." European Union Politics 13 (2): 246-68.

Dolezal, Martin, Laurenz Ennser-Jedenastik, Wolfgang C. Müller, and Anna Katharina Winkler. 2014. "How Parties Compete for Votes: A Test of Saliency Theory." European Journal of Political Research 53 (1): 57-76.

Farrell, Henry, and Adrienne Héritier. 2004. "Inter-organizational Negotiation and Intra-organizational Power in Shared Decision Making: Early Agreements under Codecision and Their Impact on the European Parliament and Council." Comparative Political Studies 37 (10): 1184-212.

Finke, Daniel. 2012. "Proposal Stage Coalition-Building in the European Parliament." European Union Politics 13 (4): 487-512.

Finke, Daniel. 2015. "The Burden of Authorship: How Agenda-Setting and Electoral Rules Shape Legislative Behaviour." Journal of European Public Policy 23 (4): 604-23.

Genschel, Philipp, and Markus Jachtenfuchs. 2016. "More Integration, Less Federation: The European Integration of Core State Powers." Iournal of European Public Policy 23 (1): 42-49.

Gill, Jeff. 1999. "The Insignificance of Null Hypothesis Significance Testing." Political Research Quarterly 52 (3): 647-74.

Green-Pedersen, Christoffer. 2007. “The Growing Importance of Issue Competition: The Changing Nature of Party Competition in Western Europe." Political Studies 55 (3): 607-28.

Green-Pedersen, Christoffer. 2010. "Bringing Parties into Parliament: The Development of Parliamentary Activities in Western Europe.” Party Politics 16 (3): 347-69.

Green-Pedersen, Christoffer, and Peter B. Mortensen. 2010. "Who Sets the Agenda and Who Responds to It in the Danish Parliament? A New Model of Issue Competition and Agenda-Setting." European Journal of Political Research 49 (2): 257-81.

Hampshire, James. 2015. "European Migration Governance since the Lisbon Treaty: Introduction to the Special Issue." Lournal of Ethnic and Migration Studies 42 (4): 537-53.

Harmel, Robert, and Lars Svasand. 1997. "The Influence of New Parties on Old Parties' Platforms: The Cases of the Progress Parties and Conservative Parties of Denmark and Norway." Party Politics 3 (3): 315-40.

Hix, Simon. 2001. "Legislative Behaviour and Party Competition in the European Parliament: An Application of Nominate to the E.U.” Iournal of Common Market Studies 39 (4): 663-88.

Hix, Simon. 2002a. "Constitutional Agenda-Setting through Discretion in Rule Interpretation: Why the European Parliament Won at Amsterdam." British Journal of Political Science 32 (2): 259-80.

Hix, Simon. 2002b. "Parliamentary Behavior with Two Principals: Preferences, Parties, and Voting in the European Parliament." American Journal of Political Science 46 (3): 688-98.

Hix, Simon. 2005. The Political System of the European Union. New York: Macmillan.

Hix, Simon, and Bjørn Høyland. 2013. "Empowerment of the European Parliament." Annual Review of Political Science 16:171-89.
Hix, Simon, Abdul Noury, and Gérard Roland. 2007. Democratic Politics in the European Parliament. Cambridge: Cambridge University Press.

Hobolt, Sara B. 2016. "The Brexit Vote: A Divided Nation, a Divided Continent." Journal of European Public Policy 23 (9): 1259-77.

Hobolt, Sara B., Jae-Jae Spoon, and James Tilley. 2009. “A Vote against Europe? Explaining Defection at the 1999 and 2004 European Parliament Elections." British Journal of Political Science 39 (1): 93-115.

Hopmann, David N., Chirsitan Elmelund-Praestekaer, Erik Albaek, Rens Vliegenthart, and Claes H. de Vreese. 2012. "Party Media AgendaSetting: How Parties Influence Election News Coverage." Party Politics 18 (2): 173-91.

Karp, Jeffrey A., and Susan A. Banducci. 2002. "Issues and Party Competition under Alternative Electoral Systems." Party Politics 8 (1): 123-41.

Krehbiel, Keith. 1993. "Where's the Party?" British Journal of Political Science 23 (2): 235-66.

Kreppel, Amie, and George Tsebelis. 1999. "Coalition Formation in the European Parliament." Comparative Political Studies 32 (8): 933-66.

Lahav, Gallya, and Anthony M. Messina. 2005. "The Limits of a European Immigration Policy: Elite Opinion and Agendas within the European Parliament." LCMS: Journal of Common Market Studies 43 (4): 851-75.

Lavenex, Sandra. 2015. "Justice and Home Affairs: Institutional Change and Policy Continuity." In Helen Wallace, Mark A. Pollack, and Alasdair R. Young, eds., Policy-Making in the European Union. 7th ed. Oxford: Oxford University Press, 367-87.

Lindberg, Björn, Anne Rasmussen, and Andreas Warntjen. 2008. "Party Politics as Usual? The Role of Political Parties in E.U. Legislative Decision-Making." Lournal of European Public Policy 15 (8): 1107-26.

Luedtke, Adam. 2009. "Uncovering European Union Immigration Legislation: Policy Dynamics and Outcomes." International Migration 49 (2): 1-27.

McDonnell, Duncan, and Annika Werner. 2018. "Respectable Radicals: Why Some Radical Right Parties in the European Parliament Forsake Policy Congruence." Journal of European Public Policy 25 (5): 747-63.

McElroy, Gail, and Kenneth Benoit. 2010. "Party Policy and Group Affiliation in the European Parliament." British Journal of Political Science 40 (2): 377-98

Meguid, Bonnie M. 2005. "Competition between Unequals: The Role of Mainstream Party Strategy in Niche Party Success." American Political Science Review 99 (3): 347-59.

Meguid, Bonnie M. 2008. Party Competition between Unequals. Cambridge: Cambridge University Press.

Meijers, Maurits J. 2017. “Contagious Euroscepticism? The Impact of Eurosceptic Support on Mainstream Party Positions on European Integration." Party Politics 23 (4): 413-23.

Meijers, Maurits J., and Christian Rauh. 2016. "Has Eurosceptic Mobilization Become More Contagious? Comparing the 2009 and 2014 European Parliament Elections in the Netherlands and France." Politics and Governance 4 (1): 83-103.

Mudde, Cas. 2007. Populist Radical Right Parties in Europe. Cambridge: Cambridge University Press.

Otjes, Simon. 2011. "The Fortuyn Effect Revisited: How Did the LPF Affect the Dutch Parliamentary Party System?” Acta Politica 46 (4): 400424.

Otjes, Simon, and Harmen van der Veer. 2016. "The Eurozone Crisis and the European Parliament's Changing Lines of Conflict." European Union Politics 17 (2): 242-61.

Petrocik, John R. 1996. "Issue Ownership in Presidential Elections, with a 1980 Case Study.” American Journal of Political Science 40 (3): 825-50.

Plümper, Thomas, Vera E. Troeger, and Philip Manow. 2005. "Panel Data Analysis in Comparative Politics: Linking Method to Theory." European Journal of Political Research 44 (2): 327-54 
Proksch, Sven-Oliver, and Jonathan B. Slapin. 2011. "Parliamentary Questions and Oversight in the European Union." European Journal of $\mathrm{PO}_{\mathrm{O}}$ litical Research 50 (1): 53-79.

Rainey, Carlisle. 2014. “Arguing for a Negligible Effect.” American Journal of Political Science 58 (4): 1083-91.

Rasmussen, Anne. 2008. "Party Soldiers in a Non-partisan Community? Party Linkage in the European Parliament." Iournal of European Public Policy 15 (8): 1164-83.

Reif, Karlheinz, and Hermann Schmitt. 1980. "Nine Second-Order National Elections: A Conceptual Framework for the Analysis of European Election Results." European Journal of Political Research 8 (1): 3-44.

Roger, Léa, Simon Otjes, and Harmen van der Veer. 2017. "The Financial Crisis and the European Parliament: An Analysis of the Two-Pack Legislation." European Union Politics 18 (4): 560-80.

Rohrschneider, Robert. 1993. "New Party versus Old Left Realignments: Environmental Attitudes, Party Policies, and Partisan Affiliations in Four West European Countries." Journal of Politics 55 (3): 682-701.

Schattschneider, Elmer E. 1960. The Semisovereign People: A Realist's View of Democracy in America. New York: Holt, Rinehart \& Winston.

Slapin, Jonathan B., and Sven-Oliver Proksch. 2010. "Look Who's Talking: Parliamentary Debate in the European Union." European Union Politics 11 (3): 333-57.

Spoon, Jae-jae, Sara B. Hobolt, and Catherine E. de Vries. 2014. "Going Green: Explaining Issue Competition on the Environment.” European Journal of Political Research 53 (2): 363-80.

Thierse, Stefan. 2019. "Policy Entrepreneurship in the European Parliament: Reconsidering the Influence of Rapporteurs." Lournal of European Public Policy 26 (2): 267-85.

Trauner, Florian. 2016. “Asylum Policy: The EU's 'Crises' and the Looming Policy Regime Failure.” Journal of European Integration 38 (3): 311-25.

Treib, Oliver. 2014. "The Voter Says No, but Nobody Listens: Causes and Consequences of the Eurosceptic Vote in the 2014 European Elections." Journal of European Public Policy 21 (10): 1541-54.

Tsebelis, George. 1994. "The Power of the European Parliament as a Conditional Agenda Setter." American Political Science Review 88 (1): 12842 . van der Brug, Wouter, Meindert Fennema, and Jean Tillie. 2005. "Why Some Anti-immigrant Parties Fail and Others Succeed: A Two-Step Model of Aggregate Electoral Support." Comparative Political Studies 38 (5): 537-73.

van de Wardt, Marc. 2015. "Desperate Needs, Desperate Deeds: Why Mainstream Parties Respond to the Issues of Niche Parties." West European Politics 38 (1): 93-122.

van Spanje, Joost. 2010. “Contagious Parties: Anti-immigration Parties and Their Impact on Other Parties' Immigration Stances in Contemporary Western Europe." Party Politics 16 (5): 563-86.

Vliegenthart, Rens, Stefaan Walgrave, and Corine Meppelink. 2011. "Interparty Agenda-Setting in the Belgian Parliament: The Role of Party Characteristics and Competition." Political Studies 59 (2): 368-88.

Vliegenthart, Rens, Stefaan Walgrave, and Brandon Zicha. 2013. "How Preferences, Information and Institutions Interactively Drive AgendaSetting: Questions in the Belgian Parliament, 1993-2000." European Journal of Political Research 52 (3): 390-418.

Volkens, Andrea, Judith Bara, Ian Budge, Michael D. McDonald, and HansDieter Klingemann, eds. 2013. Mapping Policy Preferences. Vol. 3, Statistical Solutions for Manifesto Analysis. Oxford: Oxford University Press.

Wagner, Markus. 2012a. "Defining and Measuring Niche Parties." Party Politics 18 (6): 845-64.

Wagner, Markus. 2012b. "When Do Parties Emphasise Extreme Positions? How Strategic Incentives for Policy Differentiation Influence Issue Importance." European Journal of Political Research 51 (1): 64-88.

Willumsen, David M., and Patrik Öhberg. 2017. "Toe the Line, Break the Whip: Explaining Floor Dissent in Parliamentary Democracies.” West European Politics 40 (4): 688-716.

Wonka, Arndt. 2008. "Decision-Making Dynamics in the European Commission: Partisan, National or Sectoral?" Journal of European Public Policy 15 (8): 1145-63.

Yordanova, Nikoleta. 2016. "Collusion in Bicameral European Union Decision Making: The Impact of Early Agreements on Representation and Committee Influence in the European Parliament." In Ferdinand MüllerRommel and Fernando Casal Bértoa, eds., Party Politics and Democracy in Europe Essays in Honour of Peter Mair. London: Routledge, 178-93. 